\title{
Phthiraptera and Gamasida Parasites of Columbina picui (Temminck) (Columbiformes: Columbidae) in the State of Rio Grande do Sul, Southern Brazil
}

\author{
Coimbra, MAA. ${ }^{a}$, Mascarenhas, CS. ${ }^{b *}$, Müller, . $^{b}$ and Brum, JGW. ${ }^{b}$ \\ ${ }^{a}$ Núcleo de Reabilitação da Fauna Silvestre, Centro de Triagem de Animais Silvestres, \\ Universidade Federal de Pelotas - UFPel, CP 354, CEP 96010-900, Pelotas, RS, Brazil

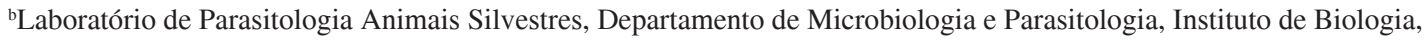 \\ Universidade Federal de Pelotas - UFPel, CP 354, CEP 96010-900, Pelotas, RS, Brazil \\ *e-mail: phrybio@hotmail.com \\ Received May 23, 2011 - Accepted August 2, 2011 - Distributed August 31, 2012
}

\begin{abstract}
Thirty-two specimens of Columbina picui (picui ground-dove) were examined, and a collection of arthropods was made by washing the external surface of the body and the nasal cavity. The species in the order Phthiraptera found and their respective prevalences, mean abundance and mean intensity were: Columbicola passerinae $(84.4 \% ; 10.3 ; 12.2)$, Hohorstiella passerinae $(21.9 \% ; 0.7 ; 3.1)$ and Physconelloides eurysema $(3.1 \% ; 0.1 ; 2)$. The gamasid mites found in the birds and their respective prevalences, mean abundance and mean intensity were: Pellonyssus marui $(31.3 \% ; 1.2 ; 3.9)$, Ornithonyssus bursa $(15.6 \% ; 0.2 . ; 1.2)$ and Mesonyssus sp. $(6.3 \% ; 0.1 ; 1)$. Columbicola passerinae, H. passerinae, $P$. eurysema, O. bursa, P. marui and Mesonyssus sp. were recorded for the first time infecting C. picui in Brazil. Except for $O$. bursa, the other species are reported for the first time in the state of Rio Grande do Sul, Brazil.
\end{abstract}

Keywords: chewing lice, mites, picui ground-dove.

\section{Phthiraptera e Gamasida parasitos de Columbina picui (Temminck) (Columbiformes: Columbidae) no sul do Rio Grande do Sul, Brasil}

\begin{abstract}
Resumo
Foram examinados 32 espécimes de Columbina picui (rolinha-picui), sendo que a coleta de artrópodes foi realizada por meio de lavagem da superfície externa do corpo e da cavidade nasal. As espécies da ordem Phthiraptera encontradas e suas respectivas prevalências, abundância média e intensidade média foram: Columbicola passerinae (84,4\%; 10,3; 12,2), Hohorstiella passerinae $(21,9 \% ; 0,7 ; 3,1)$ e Physconelloides eurysema $(3,1 \% ; 0,1 ; 2)$. Os ácaros Gamasida encontrados nas aves e suas respectivas prevalências, abundância média e intensidade média foram: Pellonyssus marui $(31,3 \% ; 1,2 ; 3,9)$, Ornithonyssus bursa $(15,6 \% ; 0,2 ; 1,2)$ e Mesonyssus sp. $(6,3 \% ; 0,1 ; 1)$. Columbicola passerinae, H. passerinae, P. eurysema, O. bursa, P. marui e Mesonyssus sp. são relatados pela primeira vez parasitando $C$. picui no Brasil. Exceto $O$. bursa, as demais espécies são relatadas pela primera vez no estado do Rio Grande do Sul, Brasil.
\end{abstract}

Palavras-chave: malófagos, ácaros, rolinha-picui.

\section{Introduction}

The picui ground-dove, Columbina picui (Temminck, 1813), occurs in South America and is found in Argentina, Chile, Uruguay, Paraguay, Bolívia, Colombia, Peru and Brazil (Del Hoyo et al., 1997). In Rio Grande do Sul it has been observed in all seasons of the year and is found in the whole state except in those areas of the northeast with an altitude of more than $800 \mathrm{~m}$ (Belton, 2004).

There are only records of chewing lice (Insecta: Phthiraptera) from C. picui in South America, where they were cited Hohorstiella passerinae Hill and Tuff, 1978 in Argentina (Cicchino, 1978), Columbicola passerinae (Wilson, 1941) (Clayton and Price, 1999) and Physconelloides eurysema (Carriker, 1903) (Price et al., 1999) both in Argentina and Bolivia.

\section{Material and Methods}

Thirty-two individual of $C$. picui from the municipalities of Pelotas and Capão do Leão, Rio Grande do Sul, Brazil were examined with the objective of identifying their chewing louse and gamasid mite parasites. Twenty-nine birds were collected using a compressed air rifle between December, 2006 and June, 2007, and euthanasia was accomplished by injection of $2 \%$ lidocane hydrochlorid 
in the cerebral stem; three were donors after death at the Núcleo de Reabilitação da Fauna Silvestre (NURFS) $e$ Centro de Triagem de Animais Silvestres (CETAS) of the Federal University of Pelotas (UFPel). These three birds were examined for arthropod collection immediately after death.

An adaptation of the technique of Lipovsky (1951) was used for the collection of arthropods on the feathers and body where each bird was individually bathed in buckets with $10 \mathrm{~L}$ of water and washing-up liquid $(50 \mathrm{~mL})$ for approximately 10 minutes, and the contents were sieved using a $63 \mu \mathrm{m}$ sieve. The nasal mites were collected using an adaptation of the technique of Fain (1957) cited by Amaral and Rebouças (1974) which consisted of opening the nasal fossas with an incision splitting the nostril to the external orifice of the ear to the corresponding bilateral side thus permitting that the upper head be opened up. The interior of the nasal fossas was washed and its contents and mucosa examined by stereo microscope. The collected arthropods were fixed in $70^{\circ} \mathrm{GL}$ alcohol for later mounting and identification.

The chewing lice were permanently mounted according to the technique of Palma (1978) and identified according to Hill and Tuff (1978), Cicchino (1978), Clayton and Price (1999) and Price et al. (1999).

The mites were cleared in lactophenol and mounted in permanent preparations. The Macronyssidae mites were identified according to Radovsky and Estébanes-Gonzalez (2001), and the Rhinonyssidae according to Crossley Junior (1952).

The encountered examples were deposited in the arthropod collection of the Laboratório de Parasitologia de Animais Silvestres, Departamento de Microbiologia e Parasitologia of the UFPel, with the numbers 283-344.

The parameters of prevalence, mean abundance and mean intensity of parasitism were evaluated according to Bush et al. (1997).

\section{Results}

Out of the 32 examples of C. picui examined, $84.4 \%$ were parasitised by Phthiraptera and $43.8 \%$ by Gamasida. Among the chewing lice encountered, $C$. passerinae was most prevalent (84.4\%), followed by H. passerinae (21.9\%) and P. eurysema (3.1\%). The mean abundance, and mean intensity of $C$. passerinae, $H$. passerinae and $P$. eurysema were respectively, $10.3,12.2 ; 0.7,3.1 ; 0.1,2$.

The gamasid mites found in the birds and their respective prevalences, mean abundance and mean intensity were: Pellonyssus marui Yunker and Radovsky, 1966 (31.3\%; 1.2; 3.9), Ornithonyssus bursa (Berlese, 1888) (15.6\%; 0.2 . ;1.2) and Mesonyssus sp. $(6.3 \% ; 0.1 ; 1)$.

Out of the 29 birds positive for Phthiraptera, 7 had double infestations ( $C$. passerinae and H. passerinae), and one bird even had a triple infestation $(C$. passerinae, $H$. passerinae and P. eurysema). Out of the 14 birds positive for Gamasida, two had double infestations ( $O$. bursa and P. marui).

\section{Discussion}

Hill and Tuff (1978) in the United States described H. passerinae from specimens collected from Columbina passerina (Linnaeus, 1758) and Columbina inca (Lesson, 1847). In the same year Cicchino (1978) described the same species from C. picui in Argentina.

Clayton and Price (1999) recorded C. passerinae from Columbina passerina in the United States, México, British Antillean Islands, Cuba, Virgin Islands, Colombia, and Venezuela; from Columbina talpacoti (Temminck, 1811) in México, Colombia, and Trinidad and Tobago; from Columbina minuta (Linnaeus, 1766) in Guiana and Trinidad and Tobago; from C. picui in Argentina and Bolívia; from $C$. inca in the United States; from Claravis pretiosa (Ferrari-Perez, 1886) in Colombia, México and Venezuela; and from Claravis mondetoura (Bonaparte, 1856) in Colombia and Costa Rica.

Price et al. (1999) reported $P$. eurysema from $C$. mondetoura in Costa Rica; from C. minuta in Trinidad and Tobago, Guiana, Venezuela and Brazil; from $C$. passerina in the United States, México, Salvador, Cuba, Cayman Islands, Colombia, Venezuela, and Panama; from C. pretiosa in México, Colombia, Brazil, Paraguay, Peru, and Venezuela; from C. talpacoti in Trinidad and Tobago, Nicaragua, México and Colombia; from C. picui in Bolivia and Argentina; and from C. inca in Mexico and the United States.

In Brazil, $P$. eurysema was initally described by Guimarães (1936) parasitizing C. minuta in Mato Grosso. Oniki (1999) reported P. eurysema and C. passerinae in C. talpacoti in the same state, and Roda and Farias (1999) reported $C$. passerinae from $C$. talpacoti and C. minuta in Pernambuco. In Rio de Janeiro, Valim et al. (2004) found $C$. passerinae, P. eurysema and $H$. passerinae parasitizing C. talpacoti with prevalences of $50 \%, 50 \%$ and $17 \%$ respectively.

Ornithonyssus bursa, known as the tropical fowl mite or chicken louse, is distributed in tropical and subtropical regions as a parasite of domestic and wild birds. In domestic birds, it is recognized that intense infestations can cause irritation, anemia and even death of chicks, even abandonment of hatchlings (Flechtmann, 1985; Guimarães et al., 2001). This mite was already reported as a causitive agent of alergic dermatitis in human beings (Ribeiro et al., 1992; Semenas and Rocha, 1998). Pelonyssus marui was reported by Radovsky and Estébanes-Gonzalez (2001) in Mexico parasitizing other Columbiformes (C. inca, C. passerina and Leptotila verreauxi Bonaparte, 1855) and some Passeriformes Hirundo rustica Linnaeus, 1758 and Campylorhynchus gularis Sclater, 1861.

The low intensity of infestation of $O$. bursa and P. marui, is probably related to the fact that they are present in major number in the nests of the birds (Flechtmann, 1985). One male individual was infested by 27 mites of the species P. marui, which can indicate that this bird was in the reproductive period, because the male as well as the female particpate in the care of the offspring (Efe et al., 2001). 
Two birds had the nasal mite Mesonyssus sp., one in each bird. Amaral (1968) cited the occurrence of various species of Mesonyssus Fain, 1960 in Columbiformes in the State of São Paulo: Mesonyssus zenaidurae (Crossley Junior, 1952) in Leptotila rufaxilla (Richard and Bernard, 1792); Mesonyssus cunhai and Mesonyssus alexfaini in L. verreauxi; and Mesonyssus melloi (Castro, 1948) in Columba livia Gmelin, 1789.

The specimens of Mesonyssus sp. found in C. picui were similar to $M$. zenaidurae described by Crossley Junior (1952) parasitizing Zenaida macroura (Linnaeus, 1758) and $C$. passerina in Mexico. The main differences between these mites was the form of the post-stimatic scutum and the number of opisthosomal ventral bristles found in the side of the anal plate that in Mesonyssus sp. there are between 13 and 17 pairs and in $M$. zenaidurae there are 11 pairs.

The representatives of the Order Phthiraptera, $C$. passerinae, $H$. passerinae and $P$. eurysema, as well as the mites $O$. bursa, P. marui and Mesonyssus sp. were first recorded parasitizing $C$. picui in Brazil; with the exception of $O$. bursa the rest of the species were recorded for the first time in the State of Rio Grande do Sul, Brazil.

Acknowledgements - We are grateful to IBAMA (Instituto Brasileiro do Meio Ambiente e dos Recursos Naturais Renováveis) for the license (066/2006/DITEC-RS) to capture the birds.

\section{References}

AMARAL, V., 1968. Notas sobre ácaros nasais com a descrição de duas novas espécies: Ptilonyssus zeferinoi $\mathrm{n}$. sp. e Sternostoma clementei n. sp. (Acarina: Rhinonyssidae). Lista das espécies descritas no Brasil e seus hospedeiros. Arquivos do Instituto Biológico, vol. 35, p. 107-126.

AMARAL, VD. and REBOUÇAS, MM., 1974. Métodos para o estudo de ácaros rinonissídeos. São Paulo: Instituto Biológico de São Paulo. 31 p.

BELTON, W., 2004. Aves silvestres do Rio Grande do Sul. 4. ed. Porto Alegre: Fundação Zoobotânica do Rio Grande do Sul. 175 p.

BUSH, AO., LAFFERTY, KD., LOTZ, JM. and SHOSTAK, AW., 1997. Parasitology meets ecology on its own terms: Margolis et al. Revisited. The Journal of Parasitology, vol. 83, p. $575-583$.

CICCHINO, AC., 1978. Contribucion al conocimiento de los malofagos argentinos II. Hohorstiella picui n. sp., parasita de Columbina picui picui (Temminck) (Mallophaga - Menoponidae). Revista de la Sociedad Entomológica Argentina, vol. 37, p. 67-71.

CLAYTON, DH. and PRICE, RD., 1999. Taxonomy of new world Columbicola (Phthiraptera: Philopteridae) from the Columbiformes (Aves), with descriptions of five New Species. Annals of the Entomological Society of America, vol. 92, p. 675-685.
CROSSLEY JUNIOR, DA., 1952. Two new nasal mites from columbiform birds. The Journal of Parasitology, vol. 38, p. 385-390. PMid:12991132. http://dx.doi.org/10.2307/3273918

DEL HOYO, J., ELLIOTT, A. and SARGATAL, J., 1997. Handbook of the birds of the world. Barcelona. 680 p. vol. 4, Sandgrouse to Cuckoos.

EFE, MA., MOHR, LV. and BUGONI, L., 2001. Guia ilustrado das aves dos Parques de Porto Alegre. Porto Alegre: PROAVES, SMAM, COPESUL, CEMAVE. $144 \mathrm{p}$.

FLECHTMANN, CHW., 1985. Ácaros de importância médico veterinária. 3. ed. São Paulo: Nobel. 192 p.

GUIMARÃES, LR., 1936. Contribuições para o conhecimento dos Mallophagas das aves do Brasil IV - Dois novos gêneros e uma nova espécie da família Philopteridae. Revista do Museu Paulista, vol. 20, p. 221-228.

GUIMARÃES, JH., TUCCI, EC. and BARROS-BATTESTI, DM., 2001. Ectoparasitos de Importância Veterinária. São Paulo: Plêiade. 213 p.

HILL, WW. and TUFF, DW., 1978. A review of the Mallophaga parasitizing the Columbiformes of North America north of Mexico. Journal of the Kansas Entomological Society, vol. 51, p. 307-327.

LIPOVSKY, LJA., 1951. Washing method of ectoparasite recovery with particular reference to chiggers. Journal of the Kansas Entomological Society, vol. 24, p. 151-156.

ONIKI, Y., 1999. Avian parasites and notes on habits of lice from Mato Grosso, Brazil. Iheringia, Série Zoologica, vol. 86, p. 183-190.

PALMA, RL., 1978. Slide-mounting of lice: a detailed description of the Canada Balsan technique. The New Zealand Entomologist, vol. 6, p. 432-436. http://dx.doi.org/10.1080/00779962.1978.9722313

PRICE, RD., CLAYTON, DH. and HELLENTHAL, RA., 1999. Taxonomic review of Physconelloides (Phthiraptera: Philopteridae) from the Columbiformes (Aves), including descriptions of three new species. Journal of Medical Entomology, vol. 36, p. 193-206.

RADOVSKY, FJ. and ESTÉBANES-GONZALEZ, ML., 2001. Macronyssidae in wild bird nests in Mexico, including new synonymies, and the genus Pellonyssus in the new world (Acari: Mesostigmata). Acta Zoologica Mexicana, vol. 82, p. 19-28.

RIBEIRO, VLS., MOOJEN, V. and TELLES, APD., 1992. Caso clínico: Ornithonyssus bursa: parasito de aves causando acaríases cutâneas em humanos no Rio Grande do Sul, Brasil. Anais Brasileiros de Dermatologia, vol. 67, p. 31-34.

RODA, AS. and FARIAS, AMI., 1999. Aves silvestres infestadas por Phthiraptera (Insecta) na Zona da Mata Norte de Pernambuco, Brasil. Revista Brasileira de Zoologia, vol. 16, p. 871-878. http:// dx.doi.org/10.1590/S0101-81751999000300024

SEMENAS, L. and ROCHA, JA., 1998. Un motivo poco común de crisis de llanto en un recién nacido. Archivos Argentinos de Pediatria, vol. 96, p. 131-133.

VALIM, MP., SERRA-FREIRE, RT., FONSECA, MA. and SERRAFREIRE, NM., 2004. Níveis de enzootia por ectoparasitos em amostras de rolinha [Columbina talpacoti (Temminck, 1810)] no Rio de Janeiro, Brasil. Entomologia y Vectores, vol. 11, p. 589-598. 
